\title{
Demystifying jadeite: an underwater Maya discovery at Ek Way Nal, Belize
}

Heather McKillop ${ }^{1, *}$, George Harlow ${ }^{2}$, April Sievert ${ }^{3}$, C. Wayne Smith ${ }^{4}$ \& Michael C. Wiemann ${ }^{5}$

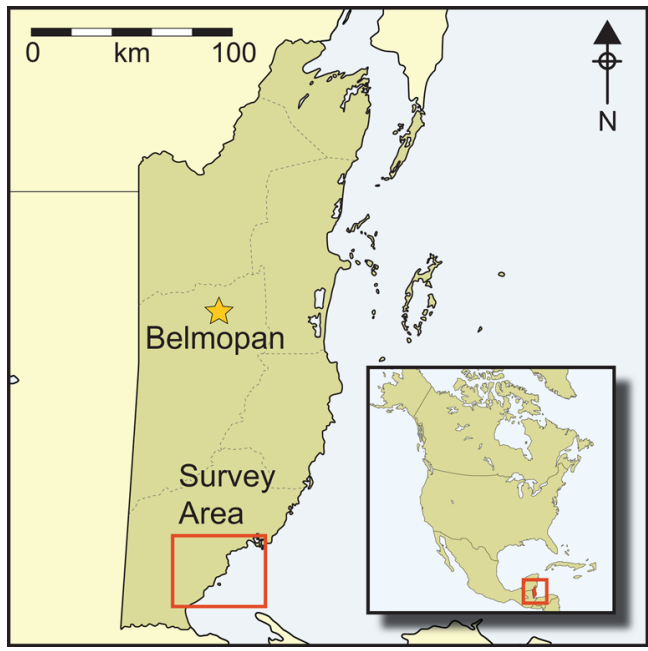

Jadeite artefacts at Maya sites are normally associated with ritual and ceremonial locations, with high-quality jadeite reserved for elite objects. The discovery of a jadeite gouge with a wooden handle at a Classic Maya saltworking site submerged by sea-level rise-Ek Way Nal, Belize-is therefore unexpected and provides new information about the utilitarian use of this stone. The extremely high quality of this jadeite tool is particularly surprising, offering new insight into the Classic Maya exchange systems and the role of salt makers such as those based at Ek Way Nal.

Keywords: Belize, Classic Maya, jadeite, underwater archaeology, use-wear

\section{Introduction}

The ancient Maya used jadeite objects in burials, caches and other ceremonial contexts from the Middle Preclassic to Postclassic periods (1000 BC-AD 1500; Figure 1; Aoyama et al. 2017). During the Classic Period (AD 300-900), the use of high-quality translucent jadeite was typically reserved for unique and elaborate jadeite plaques, figurines and earplugs (earrings) for royalty and other elites (Kovacevich \& Callaghan 2018). Craft workers closely affiliated with Maya royalty probably finished making these jadeite objects in either palace workshops or household workshops in lowland Maya cities. Debitage from sawing jadeite,

1 Department of Geography \& Anthropology, Louisiana State University, Baton Rouge, LA 70803, USA

2 Department of Earth \& Planetary Sciences, American Museum of Natural History, New York, NY 10024, USA

3 Department of Anthropology, Indiana University, Bloomington, IN 47405, USA

4 Department of Anthropology, TAMU 4352, Texas A\&M University, College Station, TX 77843, USA

5 Center for Wood Anatomy Research, USDA, Forest Products Lab, One Gifford Pinchot Drive, Madison, WI 53726, USA

* Author for correspondence (Email: hmckill@lsu.edu)

(C) Antiquity Publications Ltd, 2019. This is an Open Access article, distributed under the terms of the Creative Commons Attribution licence (http://creativecommons.org/licenses/by/4.0/), which permits unrestricted re-use, distribution, and reproduction in any medium, provided the original work is properly cited.

ANTIQUITY 93368 (2019): 502-518 https://doi.org/10.15184/aqy.2019.35 


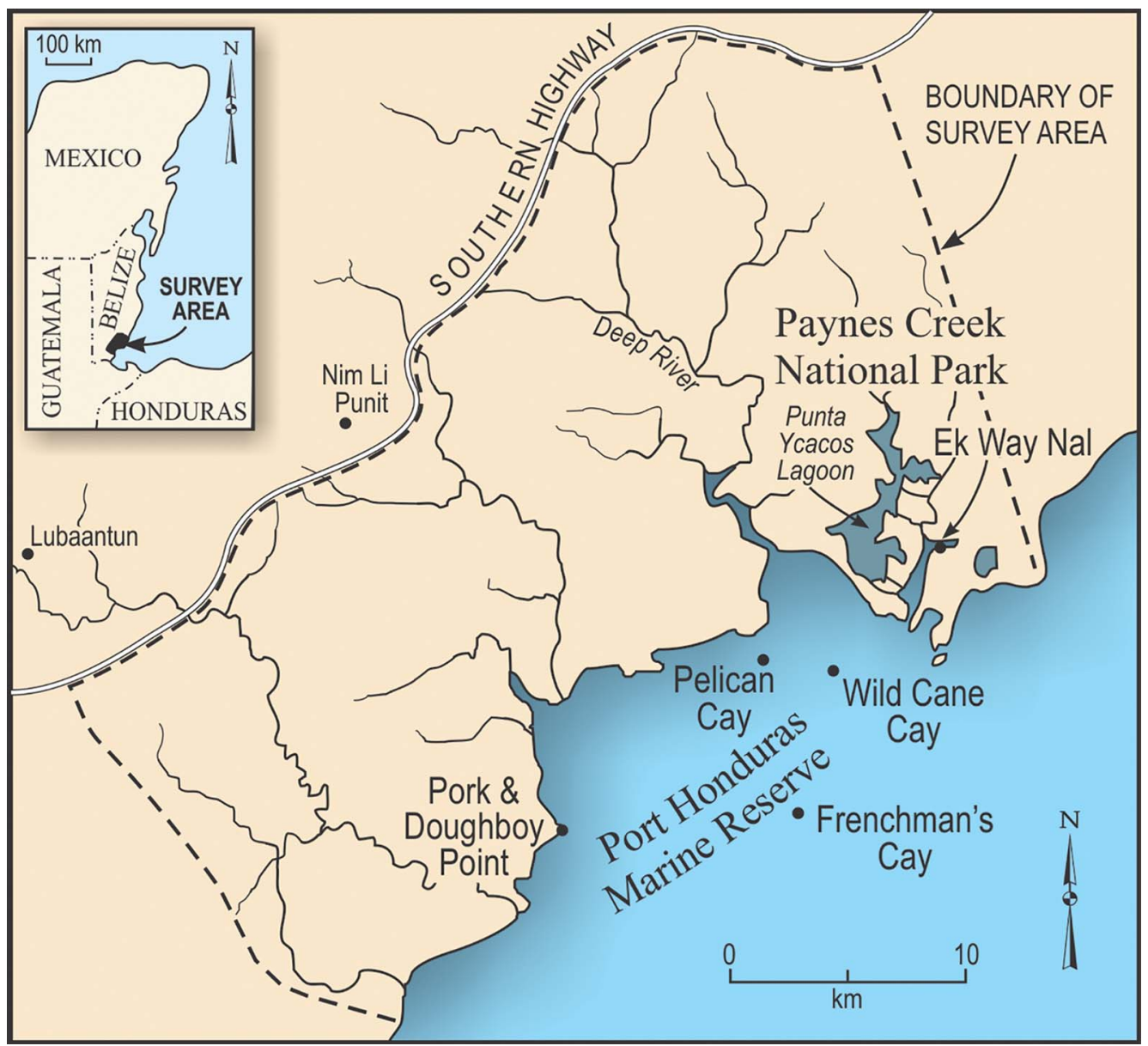

Figure 1. Map of the southern Belize survey area showing the location of Ek Way Nal in the Punta Ycacos lagoon. Inset shows location of Ek Way Nal in the Maya area (figure by Mary Lee Eggart).

for example, was recovered from above King Pacal's tomb at Palenque and in other elite contexts (Melgar et al. 2013). Highly crafted jadeite objects were destined for use in dynastic Maya ceremonies, as gifts to other leaders to solidify alliances, or as burial offerings to accompany dynastic and other elites (Halperin et al. 2018). The largest jadeite artefact $(4.4 \mathrm{~kg})$ is a depiction of the sun god from a royal tomb at Altun Ha, Belize (Pendergast 1982: fig. 33). An incised jadeite plaque from a royal burial at Nim li Punit, in Belize, resembles chest ornaments worn by dynastic leaders, who are depicted and described in hieroglyphs on stelae engaging in ritual scattering of copal incense (Prager \& Braswell 2016: figs $1 \& 8-9$ ). Jadeite had a ceremonial function as early as the Middle Preclassic (1000-300 BC), as evidenced at Ceibal, Guatemala, where dozens of jadeite and other greenstone celts (axes) were placed in caches under public plazas (Aoyama et al. 2017).

In contrast, beads and celts made from jadeite and other greenstones of varying quality were widely distributed at Tikal, Cancuen and other lowland cities, being found in

(C) Antiquity Publications Ltd, 2019 
archaeological contexts associated with both elites and commoners (Masson \& Freidel 2012; Kovacevich \& Callaghan 2018). Even at small Maya communities, such as Ceren, nearly every household had a greenstone celt (Sheets 2000). This pattern of access indicates that jadeite was available at local marketplaces, along with other trade and craft goods and resources from surplus household production. Jadeite beads, and possibly celts, may have been used as a medium of exchange (Freidel et al. 2017). Aoyama et al. (2017) demonstrated that in Middle Preclassic caches at Ceibal, a total of 23 per cent of celts made from greenstone or other rocks-including two from jadeite-had been used for wood-working prior to their deposition, whereas the other celts, including those of blue-green translucent jadeite, were unused. This suggests that, except for the finest green-blue translucent jadeite, some celts were similarly used by the Classic Maya for utilitarian purposes.

Ancient Maya stone tools are seldom recovered with their original wooden handles, as organic preservation is dependent on specific environmental conditions (Shafer \& Hester 1990: fig 9.1; Coggins \& Ladd 1992: 260-63, fig 8.37). This article presents the first report of a Maya jadeite tool—a gouge-found with its associated wooden handle. The tool was recovered from Ek Way Nal, an underwater site in southern Belize-one of 110 sites comprising the Paynes Creek Salt Works (Figure 1). The discovery of a jadeite tool in a utilitarian context is noteworthy, as high-quality translucent jadeite is normally associated with ritual or ceremonial contexts in the Maya area. The Ek Way Nal jadeite tool comes from a salt kitchen, a location that contrasts with the more typical Maya burial and cache contexts for translucent blue-green jadeite artefacts.

The Ek Way Nal tool is made of exceptionally high-quality jadeite, which is surprising given its utilitarian context. Jadeite is a hard rock that varies from translucent to opaque. The translucent appearance of the Ek Way Nal tool results from tightly woven grains in the material, which make the jadeite particularly durable and, therefore, even more desirable for use as a tool. At Ek Way Nal, salt workers probably obtained the jadeite gouge as part of a surplus household economy that related to the production and distribution of salt (McKillop 2019; McKillop \& Aoyama 2018). The gouge, along with celts made from jadeite and other minerals found elsewhere at the site, formed part of this economy. This article describes the archaeological context of the jadeite gouge and its wooden handle, as well as geological and use-wear analysis wood-species identification and the method used to conserve the handle.

\section{The Paynes Creek Salt Works}

The Paynes Creek Salt Works comprised dozens of wooden salt kitchens built by the Classic Maya (AD 300-900) along the shoreline of seasonally hyper-saline Punta Ycacos Lagoon (Figure 1). Brine was boiled in ceramic containers over fires to make salt, leaving behind briquetage as evidence (McKillop 2005a; McKillop \& Sills 2017). The thatched, wooden salt kitchens allowed for year-round production, as well as the storage of wood fuel, pots and salt. This interpretation is based on modern salt-making at Sacapulas in highland Guatemala, where salt production inside dedicated buildings occurs mainly during the dry season, but also continues during the rainy season (Reina \& Monaghan 1981). In southern Belize, there is considerable rainfall year-round, making indoor salt production desirable (McKillop 2019: fig. 4.1).

(C) Antiquity Publications Ltd, 2019 
Following their abandonment sometime after the end of the Classic Period, rapid sealevel rise flooded the salt works, leaving them underwater and invisible in the modern mangrove landscape (McKillop et al. 2010). Red mangroves (Rhizophora mangle L.) respond to more gradual sea-level rise by growing taller to keep their leaves above water; in turn, this propagates the formation of mangrove peat. The depth of the peat can be used as a proxy for measuring sea-level rise (Toscano \& Macintyre 2003). There is over $5 \mathrm{~m}$ of mangrove peat below the sea floor in the lagoon, indicating that prior to the Maya Classic Period, seas rose and then stabilised, creating land (McKillop et al. 2010). The peat also creates an anaerobic matrix that preserves wood and other organic remains. Mapping at 70 underwater sites has recorded over 4000 wooden posts defining rectangular buildings, as well as other wooden objects preserved in peat below the sea floor (McKillop 2005a, 2019; McKillop \& Sills 2017). The sites are concentrated in a $5 \mathrm{~km}^{2}$ area in Punta Ycacos Lagoon, with evidence of contemporaneous settlement elsewhere in the coastal area from the Middle Preclassic through the Postclassic (Figure 1; McKillop 2005b; McKillop \& Robertson 2018).

\section{Jadeite quarrying, exchange and craftworking}

Jadeite outcrops and quarries have been identified along both sides of the Motagua River in Guatemala (Figure 2; Hammond et al. 1977; Harlow 1993, 1994; Seitz et al. 2001; Harlow et al. 2004, 2006; Taube et al. 2004). Jadeite is one of several minerals present in the outcrops. Abrasive blocks used for shaping stone have been found at quarry sites in the middle Motagua Valley (Rochette 2009). Elite and commoner householders in nearby communities were involved in shaping raw jadeite using percussion methods, as well as in making jadeite beads, celts and plaques by sawing and drilling (Rochette 2009). Blanks or preforms, as well as finished jadeite objects from the outcrops and associated sites were widely traded to lowland Maya cities in Guatemala, Belize, Honduras and Mexico, where value was added by elite specialists who further crafted the jadeite into elaborate objects. These were gifted among dynastic and other nobles and deposited in caches and burials. Lowland Maya commoners, however, also had access to jadeite and other valuable commodities through marketplace trade, although not in the same abundance or quality as found in dynastic burials and caches.

Some Maya jadeite objects were produced in commoner household workshops in the Maya Lowlands. Jadeite objects were considered valuable commodities that could be stored and traded or gifted, for example, in times of crop failure (Rochette 2009). Workshops at Cancuen, a riverine port in the Guatemalan interior, produced jadeite beads and earplugs (Andrieu et al. 2014); elites and commoners carried out production at the Motagua River valley outcrops and at some workshops, including at Cancuen, although the Cancuen elite may have controlled the acquisition of the raw material and its distribution to other communities. Canoe trade down the Motagua River and along the Caribbean coast of Belize provided direct access to jadeite for coastal communities-including the salt workers at Ek Way Nal. Jadeite beads, for example, were interred in graves at the nearby trading port on Wild Cane Cay (McKillop 2005b: fig. 6.23; Figure 1).

(C) Antiquity Publications Ltd, 2019 

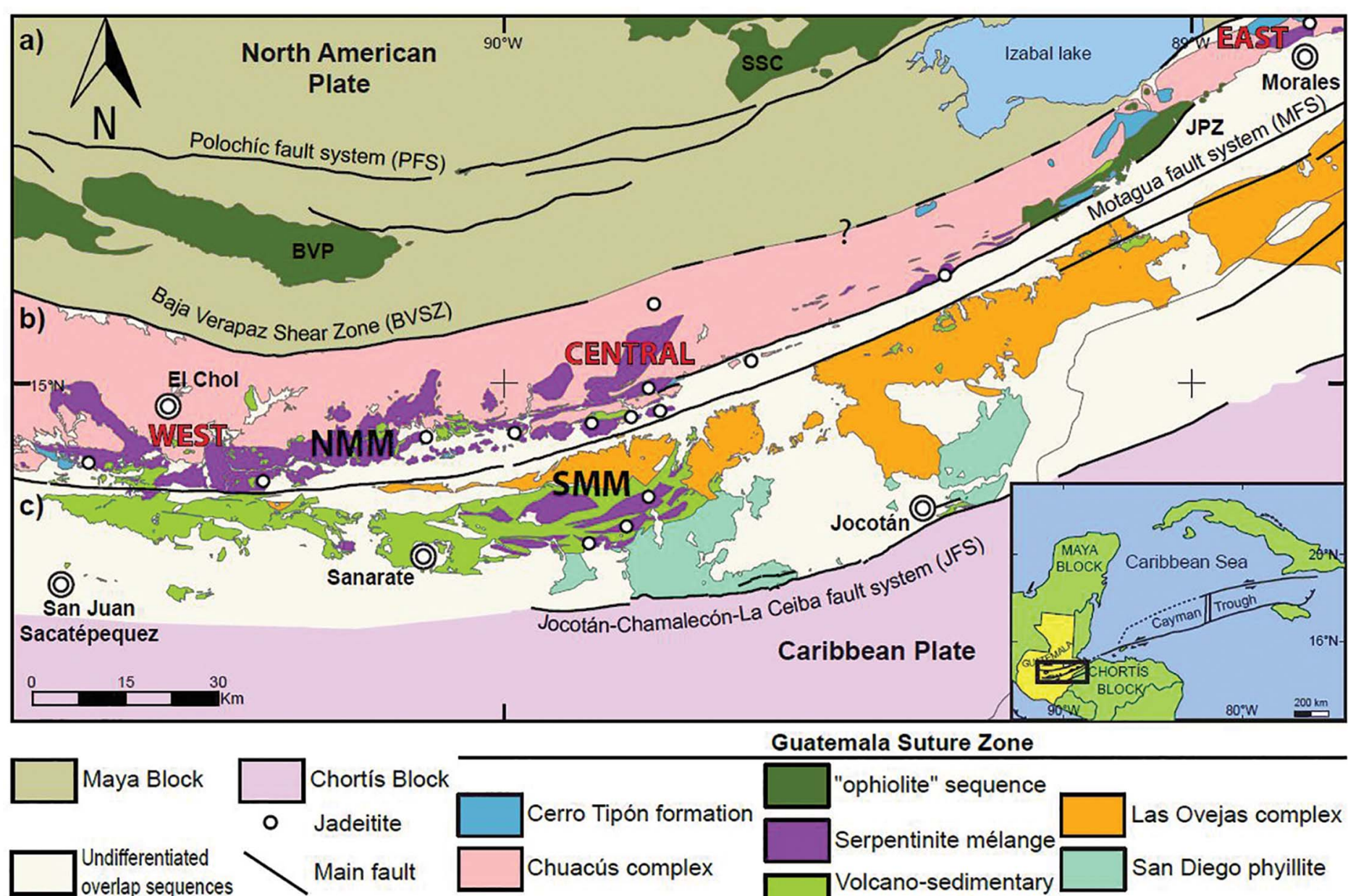

Guatemala Suture Zone

$\square$ "ophiolite" sequence

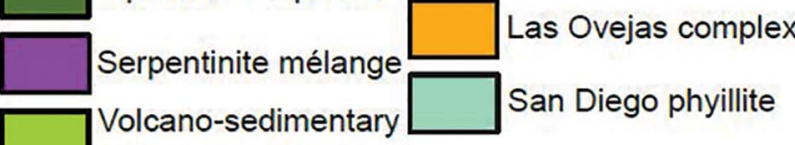
oceanic sequences

Figure 2. Map of the middle Motagua jadeite zone in Guatemala, with inset showing its location in Central America (figure by George Harlow). 


\section{Underwater survey and mapping at Ek Way Nal}

The underwater site of Ek Way $\mathrm{Nal}$ is located in the main channel of Punta Ycacos Lagoon, a large salt-water system ranging in depth from a few centimetres to over $2 \mathrm{~m}$. Systematic survey was carried out by a team of archaeologists who traversed sections of the lagoon side by side on research flotation devices (RFDs), marking the location of wooden posts and artefacts on the sea floor (Figure 3). In shallow water, survey flags were placed to mark post and artefact locations. Each location was then mapped individually using a total station and entered into the project GIS (Figure 4). Wood samples for radiocarbon dating and tree-species identification were cut from the top of 204 posts using a stainless steel kitchen knife (seven were too hard to sample); 109 were identified in the field as being made from palmetto palms (Acoelorrhaphe wrightii). In order to obtain wood free from burrowing sea worms, the mangrove peat was cleared from around a post; samples of preserved wood from the posts below the sea floor were then taken. These wood samples were placed in bags of fresh water, desalinated by periodic water changes and stored for analyses.

Clearance of peat from around post 255 revealed a jadeite gouge and its associated wooden handle (Figures 4-7). The objects were discovered leaning against a post inside a wooden salt kitchen. The tool may have originally been placed against the post, or it could have fallen

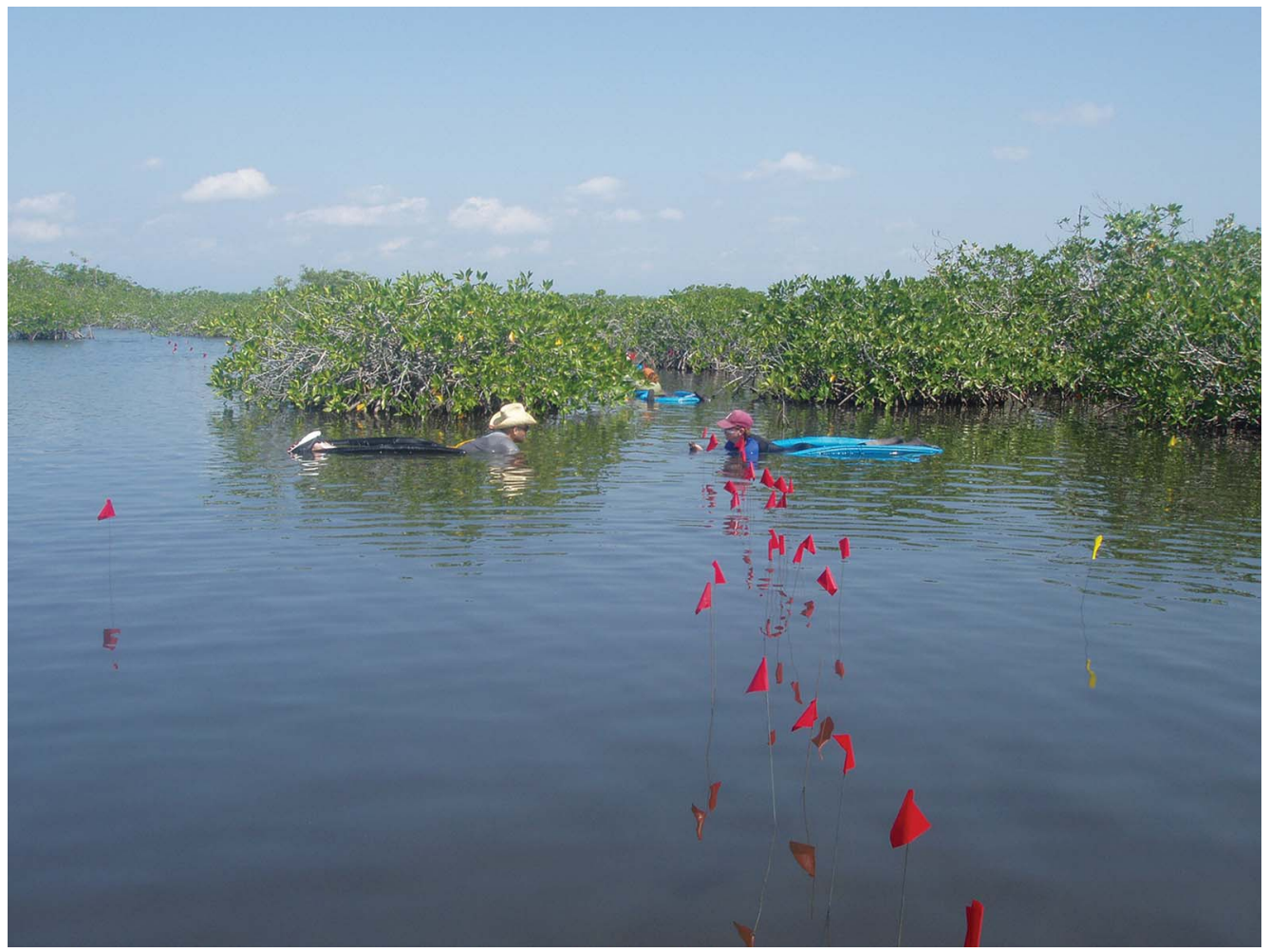

Figure 3. Survey at Ek Way Nay on RFDs (research flotation devices), with flags marking the locations of sea-floor wooden posts (photograph by Heather McKillop).

(C) Antiquity Publications Ltd, 2019 

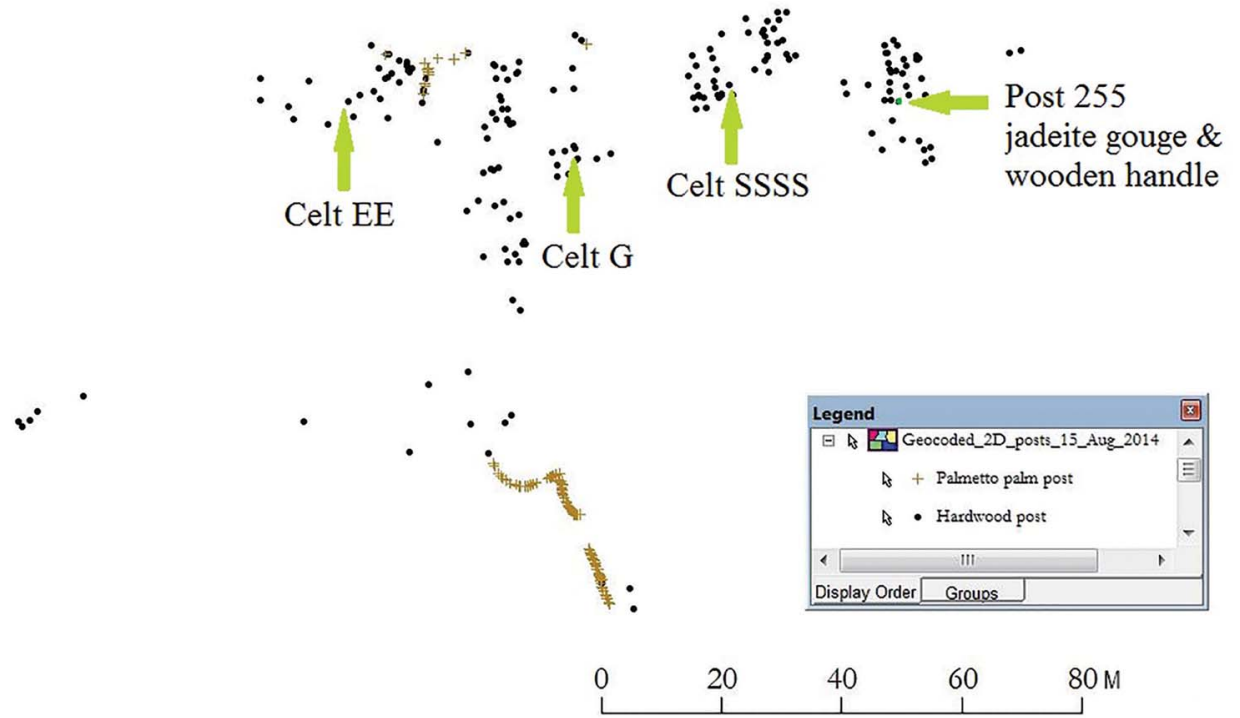

Figure 4. Distribution of wooden posts at the Ek Way Nal site; arrows indicate the locations of jadeite celts and the jadeite gouge and handle found beside post 255 (figure by Heather McKillop).

from rafters above or from a shelf, or from a hook on the post. Post 255 is of a local hardwood, prickly yellow (Zanthoxylum sp.), which is commonly used for modern building construction in southern Belize. Despite the high quality of the jadeite from which the gouge was made, the find's context is distinctly utilitarian.

Radiocarbon dates on post 255 and on the wooden handle place both in the Late (AD 600-800) to Terminal (AD 800-900) Classic Periods. An AMS measurement on the handle gives a date of cal AD $660-810(2 \sigma)$, while a standard radiocarbon date on post 255 provides an age of cal AD 680-970 (2б) (Table 1). A Late Classic date range for the site is further

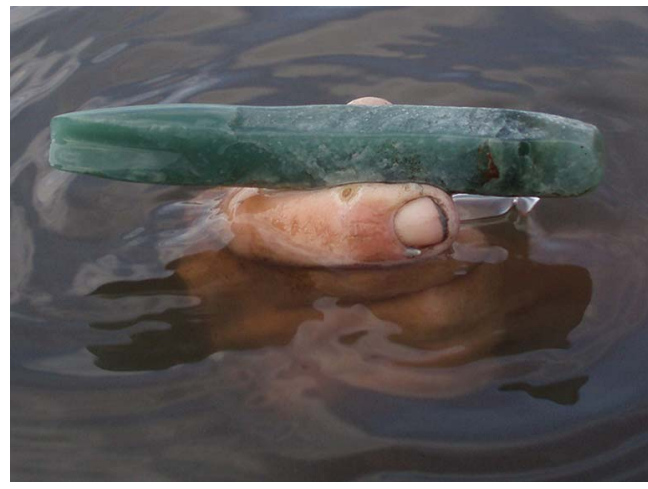

Figure 5. The jadeite gouge after discovery (photograph by Heather McKillop).

(C) Antiquity Publications Ltd, 2019 supported by Late to Terminal Classic pottery, including small quantities of chronologically distinctive pottery, such as Belize Red dishes and Warrie Red jars with characteristic stamped decorations (McKillop 2019).

\section{Mineral identification}

The jadeite gouge was analysed at the American Museum of Natural History to determine the object's chemical composition and mineral phases. The object was 


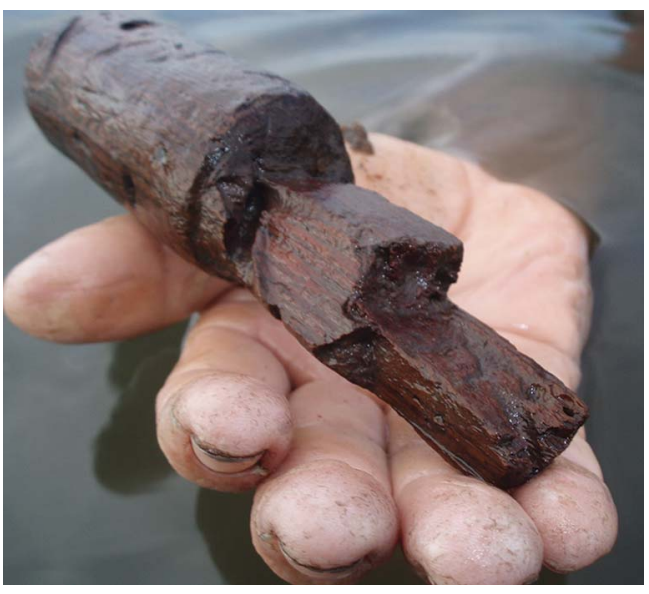

Figure 6. Wooden handle for the jadeite gouge (photograph by Heather McKillop). examined with an electron microprobe (Cameca SX100) including backscatteredelectron (BSE) images, SEM (Zeiss EVO 60 with Bruker energy-dispersive X-ray spectroscopy) and X-ray microdiffraction (Rigaku DMAX/Rapid). These analyses reveal that the tool is of exceptionally high quality and is compositionally consistent with jadeite samples from the Motagua River valley in Guatemala (Figure 8). To view the mineral microtexture and to provide a suitable sample for microprobe analysis, a small piece was removed from the non-display side of the butt end and polished. The gouge was determined to be of high quality, with around 98 vol\% jadeite, which is marginally zoned between nearly pure jadeite and approximately $10 \% \mathrm{~mol} \%$ (molar percentage of other pyroxene compositions) diopside+hedenbergite+aegirine. Other mineral phases include analcime (along some grain boundaries, or as small inclusions), omphacite (a pyroxene phase that is about half diopside and half jadeite), barian K-feldspar, zircon and titanite. This is consistent with a Guatemalan source, and resembles some of the very fine Olmec-like jade artefacts. As an example of jadeite jade, the gouge approaches the quality of so-called 'gem grade' material, in that it has a translucent blue-green colour often associated with objects from Formative (Olmec) sites. Translucency is conferred by a tight microstructure of intersecting jadeite grains; this structure also confers mechanical durability.

Petrologically, the artefact is a jadeitite with little other than pyroxene with subtle and complex zoning of tightly intergrown jadeite grains and rare small zircon and titanite grains. It is interspersed with veins of more evolved (diopside-richer) jadeitite and late complex veins of varying jadeite and omphacite compositions, with occasional barian K-feldspar grains. Jadeite grains are rhythmically zoned from $\mathrm{Jd}_{100}$ to about $\mathrm{Jd}_{90}$ - the near- 0 to $10 \mathrm{~mol} \%$ composed primarily of diopside with hedenbergite and aegirine in descending abundance. The high-quality jadeite used to make the Ek Way Nal gouge is rare, but does occur in the Guatemalan source area. Moreover, as mica, lawsonite and quartz were not detected in the composition of the jadeite, it is impossible to determine from which side of the Motagua Fault the jadeitite was sourced.

\section{Wooden handle}

Thin slices of the wooden handle were taken using a backed razor. Analysis of the wood's structure shows that the handle is made from Honduras rosewood (Dalbergia stevensonii Standl.), as indicated by the presence of characteristic storied rays. Honduras rosewood is locally available in the deciduous forest on the south side of the Deep River, and more generally in southern Belize (Figure 1; Wright et al. 1959).

The rosewood handle was conserved using the polymer method (Smith 2003) at Texas A\&M University. To provide a digital record, the wooden handle and jadeite gouge were

(C) Antiquity Publications Ltd, 2019 


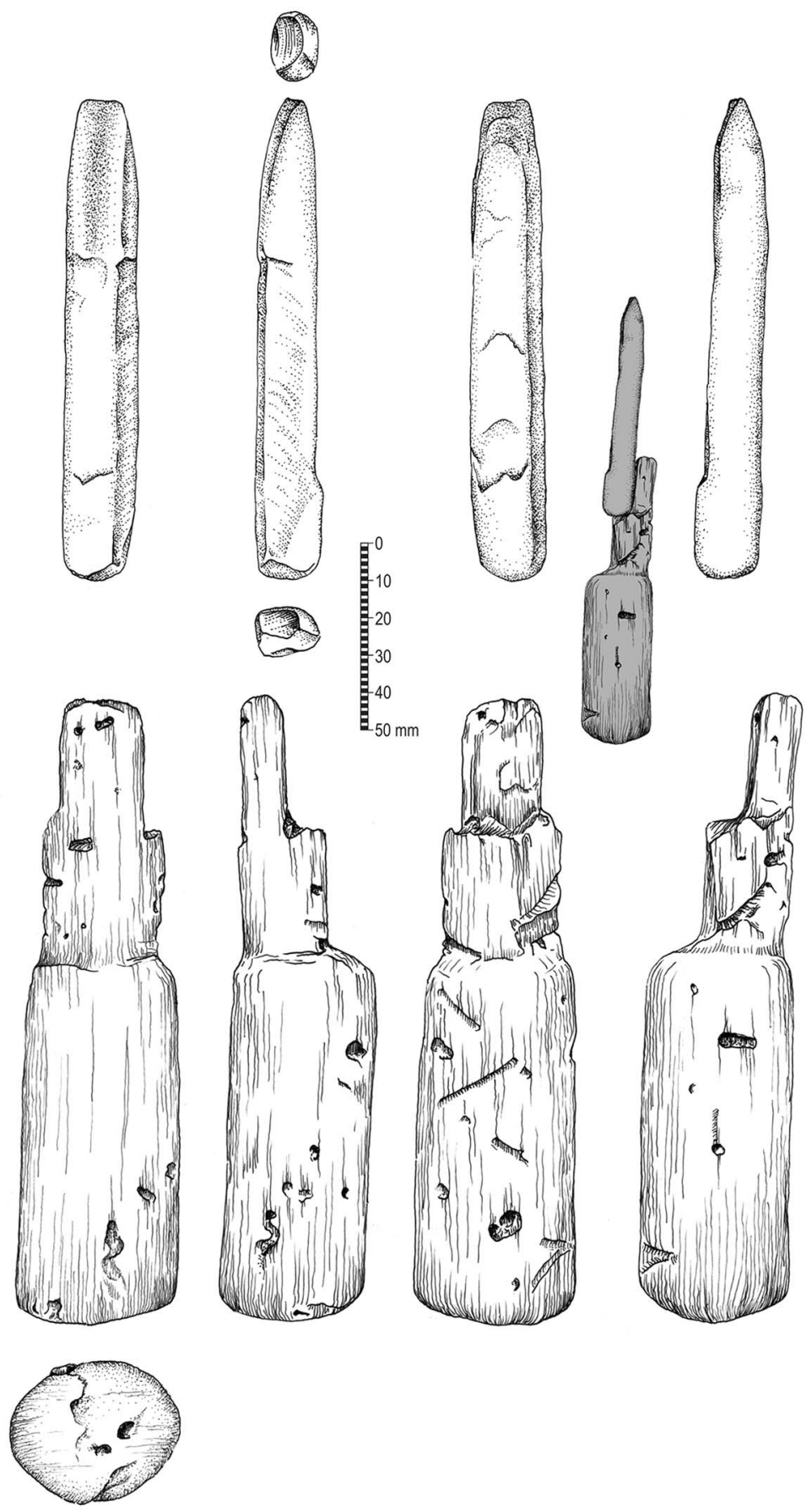

Figure 7. Drawings of the gouge and handle (figure by Mary Lee Eggart).

(C) Antiquity Publications Ltd, 2019 
Table 1. Radiocarbon dates from Ek Way Nal post 255 and from the associated wooden handle.

\begin{tabular}{|c|c|c|c|c|c|c|c|}
\hline Description & $\begin{array}{l}\text { Wood } \\
\text { species }\end{array}$ & $\begin{array}{l}\text { Common } \\
\text { wood name }\end{array}$ & $\begin{array}{c}\text { Beta } \\
\text { analytic } \\
\text { lab \# }\end{array}$ & LSU \# & $\begin{array}{c}\text { Conventional } \\
\text { age }\end{array}$ & $\begin{array}{c}\text { Calibrated } \\
2 \sigma \text { date }\end{array}$ & Method \\
\hline Post 255 & Zanthoxylum & $\begin{array}{l}\text { Prickly } \\
\text { yellow }\end{array}$ & 258747 & $\begin{array}{l}22 / 180- \\
2-p 255\end{array}$ & $1240 \pm 50 \mathrm{BP}$ & $\begin{array}{c}\mathrm{cal} A D \\
680-970\end{array}$ & Standard ${ }^{14} \mathrm{C}$ \\
\hline Handle & Dalbergia sp. & Rosewood & 258746 & $\begin{array}{l}\text { 33/180- } \\
\text { 2-handle }\end{array}$ & $1330 \pm 40 \mathrm{BP}$ & $\begin{array}{c}\mathrm{cal} A D \\
660-810\end{array}$ & AMS \\
\hline
\end{tabular}

imaged separately using a NextEngine 3D desktop scanner in the Digital Imaging and Visualization in Archaeology (DIVA) laboratory at Louisiana State University. As with previous waterlogged finds from the Paynes Creek Salt Works, printed replicas were made from the 3D scans for use in exhibitions and for public outreach (McKillop \& Sills 2013; McKillop 2016).

\section{Use-wear analysis of the jadeite gouge}

Questions regarding the jadeite artefact include the extent to which its use may have left traces along the working edge, the character of that wear and the presence of hafting traces. All of these lines of evidence may contribute towards understanding how the tool was used. The artefact resembles a gouging tool that would be used to make wide grooves, based on morphology. As with any stone tool created by grinding and abrasive polishing, it is difficult to distinguish between manufacturing- and use-related wear. The distal end of the tool has been ground and polished to a smooth surface. Both the right lateral edges of faces $\mathrm{A}$ and $\mathrm{C}$ are reflective and smooth (Figure 9). The opposite two edges (left lateral edges) are smooth only near the tip, and display considerable crushing and pecking, especially near the proximal end. A unidirectional grinding/abrasive action has produced the concave distal end of the tool (Figure 9). Clear directionality in wear parallel to the long axis of the piece is macroscopically visible. Grinding and abrading to shape the tool has resulted in highly polished surfaces on all faces at the distal end. More shaping characterises the distal end of the tool on faces A and B, with less shaping and grinding on faces $\mathrm{C}$ and $\mathrm{D}$. The sides have a matte polish that reflects less use than the deeper, central part of the groove. As the groove deepened, it may have been easier for the manufacturer to control the motion of the abrasives used in its creation. Therefore, the bottom of the groove has a more homogeneous surface than its sides.

Haft traces show abrasive wear from rubbing, as typically seen on chipped stone implements hafted in wood. Wear is present on the proximal end of the tool, particularly on face A. Although the handle was hafted close to the jadeite tool, it was sufficiently looseperhaps imperceptibly so, for the user-for haft wear traces to form (Figure 7). Visible but less well-developed hafting wear is present along the ridges on the base (proximal face) of the implement. This suggests that the implement was less tightly hafted here, resulting in less hafting wear during use. Wear traces identified along the right lateral edge of face $\mathrm{A}$ may be the result of polishing during manufacture, or due to contact with a hand during use.

(C) Antiquity Publications Ltd, 2019 


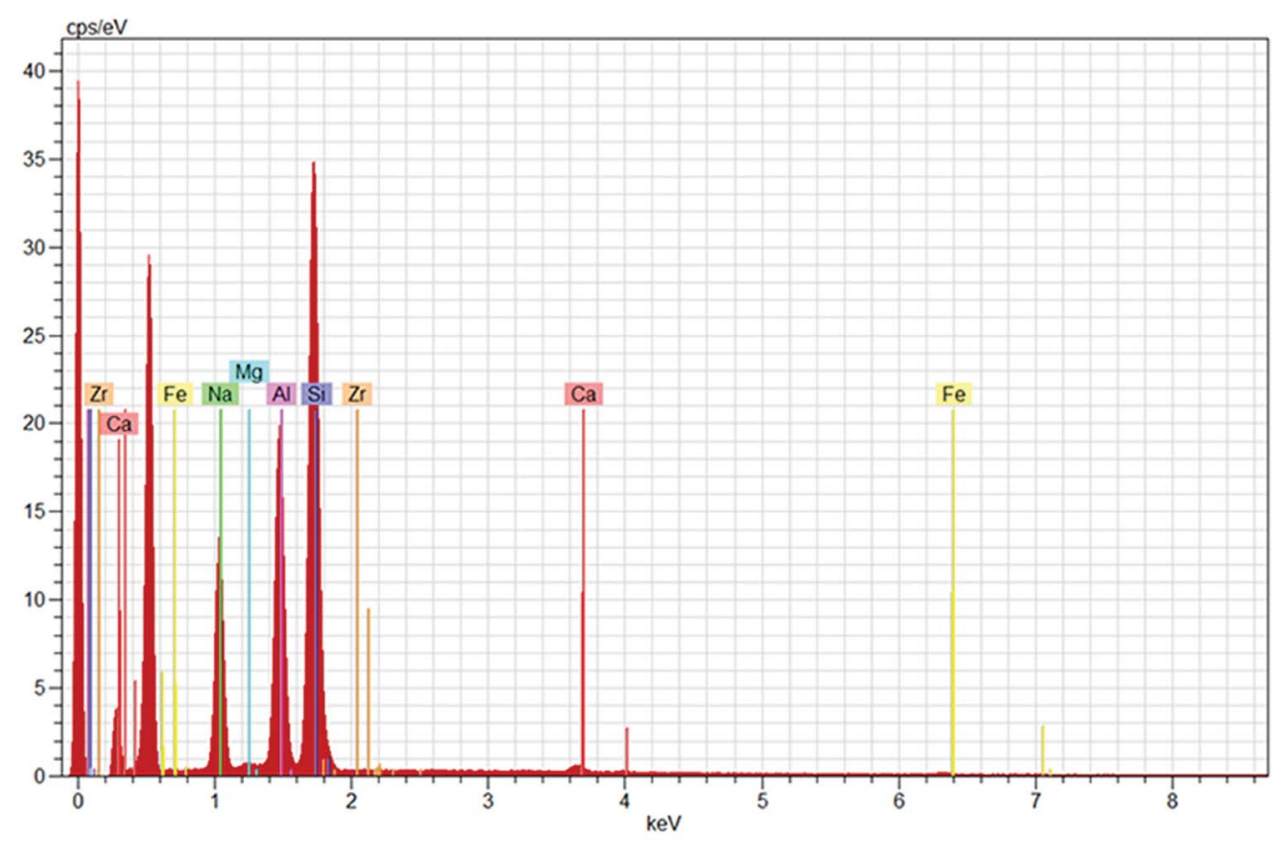

Figure 8. Energy-dispersive X-ray spectrum showing elemental abundances at dark zone in gouge that is nearly pure jadeite. $\mathrm{Zr}$ =zirconium; $\mathrm{Ca}=$ calcium; Fe=iron; $\mathrm{Na}=$ sodium; $\mathrm{Mg}=$ magnesium; $\mathrm{Al}=$ aluminium; $\mathrm{Si}=$ silicon. Bruker HV: 15.0 kV Puls th.: 6.87 kcps (figure by George Harlow).

The distal edge on face $\mathrm{C}$ was the area of contact when the jadeite implement was in use (Figure 9). Stereomicroscopic analysis shows a matte surface polish on this distal edge that probably resulted from use and edge rounding. The rounding extends along almost the entire distal edge. The polish is clearly directional, showing motion perpendicular to the edge. Neither micro flaking nor damage in the form of crushing is present along the working edge, although jadeite may be resistant to these actions. The absence of crushing implies that the worked material was not extremely hard; if the gouge had been used to work very hard material, such as stone, bone or antler, at least some crushing might be expected.

The edge rounding on the distal end is associated with a light matte polish and a slight bevel, just posterior to the working bit. If the tool was used in woodworking, a bright, spreading polish - similar to the hafting traces—-would be expected. Instead, the wear is neither as bright nor as well developed as that generated from contact with the haft. The gouge, although bearing evidence of mechanical use in the form of hafting traces on the proximal end, and a wear trace along the dorsal side of the working edge, was therefore not used to carve wood. The polish and edge modification at the tip indicate directionality perpendicular to the working edge. No distinctive polish or use-related contact is visible on face A, other than a spot of polish at the intersection of the left lateral edge and the bit. This feature runs parallel to the long axis, with visible directionality. This spot of polish might indicate contact with wood, but could also result from manufacturing. The jadeite gouge does not 

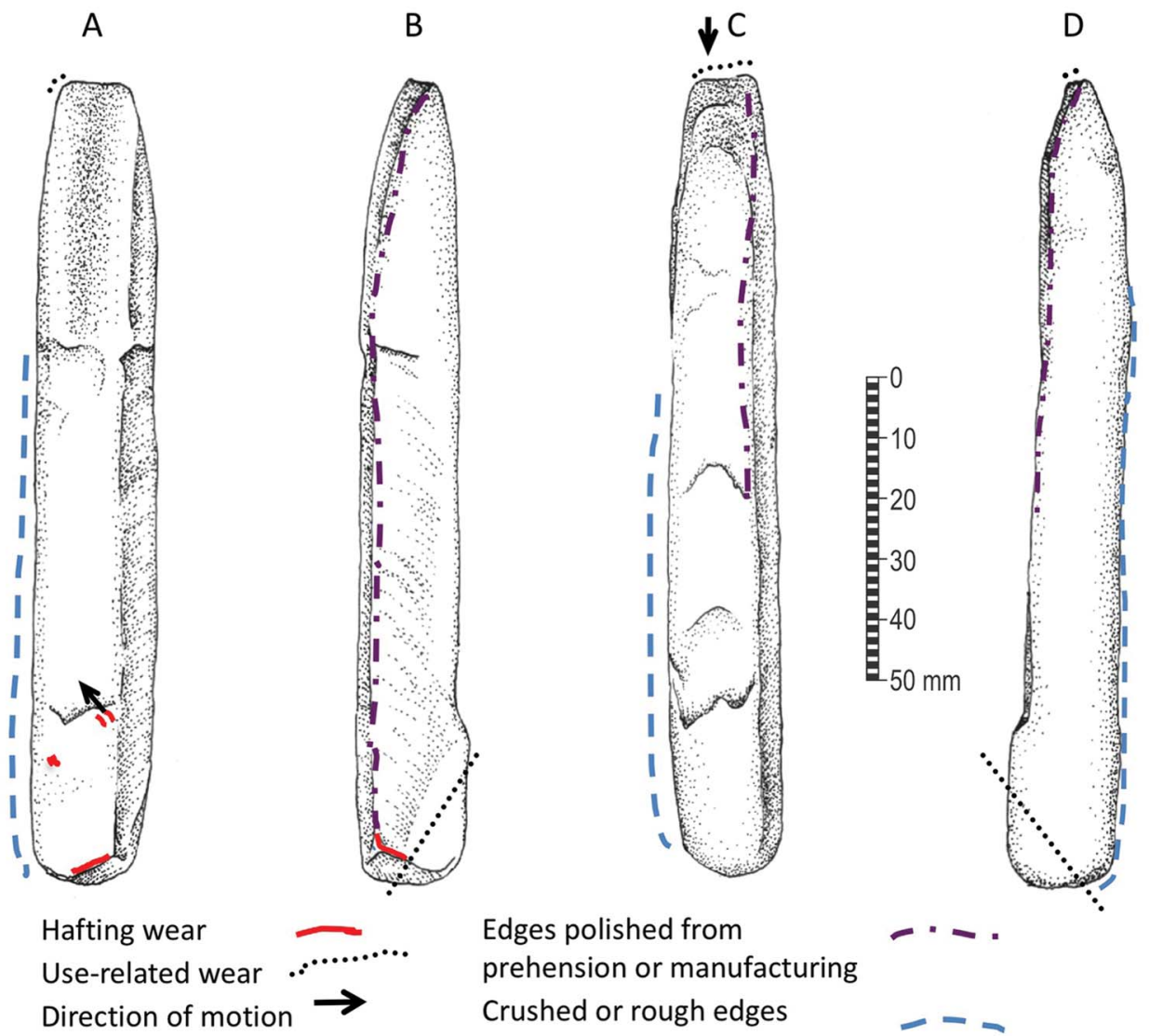

Figure 9. Drawing of jadeite gouge showing locations of wear from hafting to the wooden handle and from use (figure by April Sievert).

appear to have been used on a particularly hard material, nor does it appear to have been used primarily for woodworking. Other uses are possible but yet to be determined.

\section{Discussion}

Recovery of the jadeite gouge and handle at the Ek Way Nal salt works emphasises the probability that jadeite and other stone tools were fitted with wooden handles, which have not survived at most Maya sites. The use of jadeite as a utilitarian tool in a salt works indicates that even exotic materials, which often require expertise to fashion into tools, were selected for their hardness. Although the gouge was probably not employed in working wood or hard materials, it may have been used in other activities at the salt works, such as scraping salt, cutting and scraping fish or meat, or cleaning calabash gourds (see McKillop \& Aoyama 2018). The jadeite tool may have been obtained by the salt workers travelling to regional marketplaces with their salt cakes and salted fish (McKillop 2019). Alternatively, the salt workers

(C) Antiquity Publications Ltd, 2019 
or other mariners may have travelled to the Motagua River, which is only $70 \mathrm{~km}$ by water, and then upriver to the jadeite outcrops.

Artistic depictions, boat models from the salt works and elsewhere (McKillop 2002: fig $3.38 \mathrm{~b}-\mathrm{d}, 2017$ : fig 4) and settlement on offshore islands also indicate the use of boat and canoe navigation dating to the Classic Period (McKillop 2017). The wooden canoe paddle from the K'ak'Naab' site and a canoe from the Eleanor Betty site-two other Late Classic sites at the Paynes Creek Salt Works_provide primary evidence of boat travel in the Maya area and specifically at the Paynes Creek Salt Works (McKillop 2005a: fig. 2, 2010, 2017; McKillop et al. 2014: fig. 12).

A variety of non-local goods from Ek Way $\mathrm{Nal}$ and other sites that comprise the Paynes Creek Salt Works include figurine whistles and unit-stamped pottery from nearby inland sites, such as Lubaantun (Hammond 1975; McKillop 2002). Belize Red pottery came from farther away in the Belize River Valley; chert was probably sourced from the high-quality outcrops in northern Belize and obsidian came from the Maya highland sources of Ixtepeque and El Chayal (McKillop 2019). The salt workers produced salt that they traded at regional markets in southern Belize, acquiring other commodities in return. Some goods may have been obtained during boat trips to the Motagua outcrops or from coastal traders who stopped at the nearby trading port of Wild Cane Cay (McKillop 2005b). The salt workers, for example, obtained celts made from jadeite and other rocks that were at outcrops along the Motagua River. Figure 10 shows three such jadeite celts found at Ek Way Nal.

Salt was important to the Maya and other ancient civilisations as a dietary supplement and for the preservation of fish. Salt cakes were a commodity traded at Maya marketplaces, as still practised today by modern salt makers in the Maya highlands and elsewhere (Reina \& Monaghan 1981). Standard-sized salt cakes were traded both locally and regionally as currency equivalencies; they could be stored-along with salted fish-for later use, acting as a riskmanagement strategy to offset fluctuations in food availability (McKillop \& Aoyama 2018; McKillop 2019). Marketplace trade of staple goods and resources made both locally and farther afield is documented at Maya cities, such as Caracol and Tikal, as well as in smaller communities (Sheets 2000; Masson \& Freidel 2012; Chase et al. 2015).

\section{Conclusions}

By the Late Classic Period in the Maya lowlands, multiple spheres of local and long-distance exchange had developed for the acquisition of goods and resources (Sheets 2000; Freidel et al. 2017). Elaborate objects made of valuable imported materials circulated among the dynastic Maya rulers of lowland polities, and were used as gifts to create and maintain political alliances. Marketplace trade provided a venue for the exchange of surplus household craft production, as well as ritual and finer goods, including beads and celts made from jadeite and other greenstones. The largest quantities of exotic materials and highly crafted goods were concentrated in city centres amongst the royalty. The plaque from Nim li Punit (Prager \& Braswell 2016) — a site only a short distance from the Paynes Creek Salt Works_-provides an example of this. While Nim li Punit would have been one of the marketplace destinations for coastal salt, the plaque was probably acquired through elite gifting.

(C) Antiquity Publications Ltd, 2019 


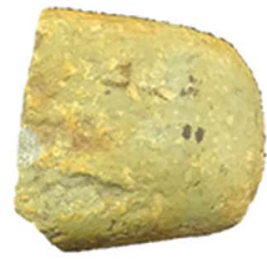

A
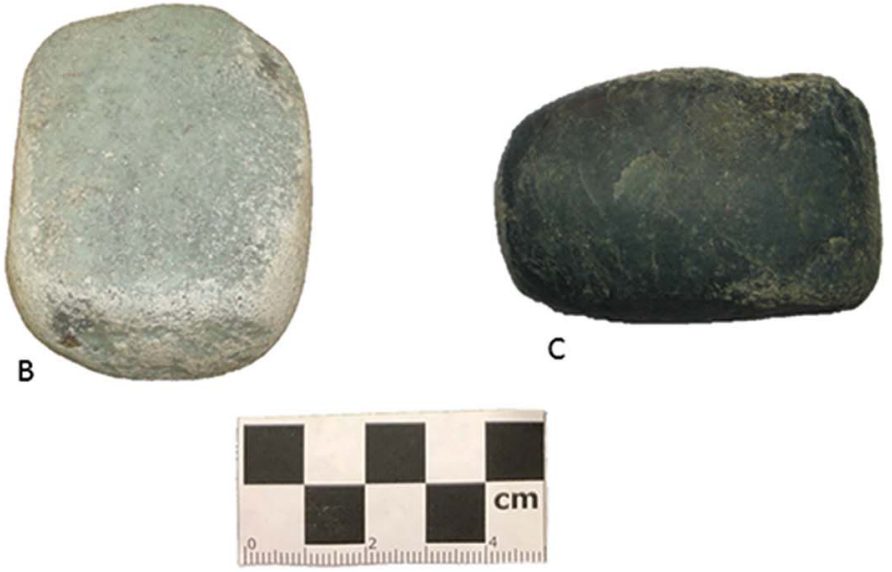

Figure 10. Jadeite celts (75 per cent jadeite and 25 per cent omphacite) from Ek Way Nal: A) 60 EE (fragment); B) 60 SSSS; C) 60 G. For celt locations at the site, see Figure 4 (figure by Cheryl Foster).

The depositional context of the Ek Way Nal gouge in a salt kitchen demonstrates that high-quality jadeite was not reserved for, or limited to, elite usage. Mineralogical and usewear analyses of the gouge show that commoners also had access to the highest-quality jadeite and that the object was used in activities relating to salt making. If not obtained through local marketplace trade, jadeite may have been transported by merchants travelling along the coastal canoe route from the Motagua River valley quarries, or have been directly procured by the salt producers or their delegates.

Without the associated wooden handle and microscopic evidence that the tool had been used before deposition, it may have been viewed as representing a ritual deposit of highquality jadeite. The translucent appearance of the almost-pure jadeite, which results from the tight microstructure of intersecting jadeite grains, made the material highly durable and desirable as a working implement. Evidently, variability in the quality and translucency of jadeite and other greenstones were important factors in the selection of raw material for making tools.

While jadeite gouges or celts are not typically part of the brine-boiling process at salt works, a greenstone celt was found in a cache at Marco Gonzalez on Ambergris Cay-a community that practised salt making, among other activities (Graham \& Pendergast 1989: fig. 10). The Ek Way $\mathrm{Nal}$ gouge and the other celts do not resemble the anvils or smooth stones used by some potters or salt workers to make pottery vessels for boiling brine (Halliwell et al. 2016). A wooden pottery paddle from the Chak Te'el K'in site, however, indicates the paddle and anvil method was used at the Paynes Creek Salt Works (McKillop 2019: fig 6.5). In this method, a pot was formed by holding a smooth stone or anvil on the inside of a clay pot and hitting the outside of the pot with a wooden paddle to shape it.

The salt workers were successful entrepreneurs who were able to obtain high-quality tools for their craft through the production and distribution of salt. A basic biological necessity that

(C) Antiquity Publications Ltd, 2019 
was in demand for the Maya diet, salt was also a storable form of wealth and an important preservative for fish and meat. The choice of high-quality materials, such as jadeite and rosewood, for use in utilitarian tools, demonstrates that the salt workers played an important role in the Classic Maya marketplace economy.

\section{Acknowledgements}

Research at Ek Way Nal was carried out by permission of the Belize Government Institute of Archaeology and funded by the National Science Foundation (grant 0513398). Field research was assisted by LSU students Bretton Somers, Cory Sills, Mark Robinson and Amanda Evans, along with Belizean John Young. We are also grateful for the friendship and hospitality of our host family in Belize: Tanya Russ, and John, Lyra and Nathaniel Spang.

\section{References}

Andrieu, C., E. Rodas \& L. Luin. 2014. The values of Classic Maya jade: a reanalysis of Cancuen's jade workshop. Ancient Mesoamerica 25: 141-65. https://doi.org/10.1017/S0956536114000108

Aoyama, K., T. Inomata, F. Pinzon \& J.M. Palomo. 2017. Polished greenstone celt caches from Ceibal: the development of Maya public rituals. Antiquity 91: 701-17. https://doi.org/10.15184/aqy.2017.44

Chase, A.F., D.Z. Chase, R.E. Terry, J.M. Horlacher \& A.S.Z. Chase. 2015. Markets among the ancient Maya: the case of Caracol, Belize, in E.M. King (ed.) The ancient Maya marketplace: 226-50. Tuscon: University of Arizona Press.

Coggins, C. \& J.M. Ladd. 1992. Wooden artifacts, in C. Coggins (ed.) Artifacts from the Cenote of Sacrifice, Chichén Itzá, Yucatán (Papers of the Peabody Museum of Archaeology and Ethnology 10): 235-44. Cambridge (MA): Harvard University.

Freidel, D.A., M. Masson \& M. Rich. 2017. Imagining a complex Maya political economy: counting tokens and currencies in image, text, and the archaeological record. Cambridge Archaeological Journal 27: 29-54. https://doi.org/10.1017/S0959774316000500

Graham, E. \& D.M. Pendergast. 1989. Excavations at the Marco Gonzalez site, Ambergris Cay, Belize, 1986. Journal of Field Archaeology 16: 1-16.

Halliwell, A., A. Yankowski \& N. Chang. 2016. Gendered labor in pottery and salt production in northeast Thailand, in S.E. Kelly \& T. Ardren (ed.) Gendered labor in specialized economies: 117-57. Boulder: University Press of Colorado.
Halperin, C.T., Z.X. Hruby \& R. Mongelluzzo. 2018. The weight of ritual: Classic Maya jade head pendants in the round. Antiquity 92: 758-71. https://doi.org/10.15184/aqy.2018.65

Hammond, N. 1975. Lubaantun: a Classic Maya realm (Monographs of the Peabody Museum of Archaeology and Ethnology 2). Cambridge (MA): Harvard University.

Hammond, N., A. Aspinall, S. Feather, J. Hazelton, T. Gazard \& S. Argell. 1977. Maya jade: source location and analysis, in T. Earle \& J. Ericson (ed.) Exchange systems in prehistory: 35-67. New York: Academic.

Harlow, G.E. 1993. Middle American jade: geologic and petrologic perspectives on its variability and source, in F.W. Lange (ed.) Precolumbian jade: new geological and cultural interpretations: 9-29. Salt Lake City: University of Utah Press.

- 1994. Jadeitites, albitites and related rocks from the Motagua Fault Zone, Guatemala. Journal of Metamorphic Geology 12: 49-68. https://doi.org/10.1111/j.1525-1314.1994. tb00003. $x$

Harlow, G.E., S.R. Hemming, H.G.A. Lallemant, V.B. Sisson \& S.S. Sorensen. 2004. Two high-pressure-low-temperature serpentine-matrix mélange belts, Motagua Fault Zone, Guatemala: a record of Aptian and Maastrichtian collisions. Geology 32: 17-20. https://doi.org/10.1130/G19990.1

Harlow, G.E., A.R. Murphy, D.J. Hozjan, C.N. De Mille \& A.A. Levinson. 2006. Pre-Columbian jadeite axes from Antigua, West Indies: description and possible sources. The Canadian Mineralogist 44: 305-21. https://doi.org/10.2113/gscanmin.44.2.305 
Kovacevich, B. \& M.G. Callaghan. 2018. Fifty shades of green: interpreting Maya jade production, circulation, consumption, and value. Ancient Mesoamerica. https://doi.org/10.1017/S0956536118000184

Masson, M.A. \& D.A. Freidel. 2012. An argument for Classic era Maya market exchange. Journal of Anthropological Archaeology 31: 455-84. https://doi.org/10.1016/j.jaa.2012.03.007

Melgar Tisoc, E., R.B. Solis Ciriaco \& L. Filloy Nadal. 2013. Análisis tecnológico de las piezas de jadeíta y pedernal del cinturón de poder y la banda frontal de K'inich Janaab' Pakal de Palenque, in A. Velázquez \& L. Lowe (ed.) Técnicas analíticas aplicadas a la characterizatión y producción de materiales arqueológicos en el Area Maya: 135-62. Mexico City: UNAM.

McKillop, H. 2002. Salt: white gold of the ancient Maya. Gainesville: University Press of Florida. https://doi.org/10.5744/florida/ 9780813025117.001 .0001

- 2005a. Finds in Belize document Late Classic Maya salt making and canoe transport.

Proceedings of the National Academy of Sciences of the USA 102: 5630-34. https://doi.org/10.1073/pnas.0408486102 - 2005b. In search of Maya sea traders. College Station: Texas A\&M University Press.

- 2010. Ancient Maya canoe navigation and their implications for Classic and Postclassic Maya economy and trade. Journal of Caribbean Archaeology, Special Publication 3: 93-105.

- 2016. Underwater Maya. Available at: http://www.underwatermaya.com (accessed 21 February 2019).

- 2017. Early Maya navigation and maritime connections in Mesoamerica, in M. Balard (ed.) The sea in history: the medieval world: 701-15. Woodbridge: Boydell.

-2019. Maya salt works. Gainesville: University Press of Florida.

McKillop, H. \& K. Aoyama. 2018. Salt and marine products in the Classic Maya economy from usewear study of stone tools. Proceedings of the National Academy of Sciences of the USA 115: 10948-52.

https://doi.org/10.1073/pnas.1803639115

McKillop, H. \& R. Robertson. 2018. Ich'ak'tun: an early maritime shell midden site on the south coast of Belize. Paper presented at the Belize Archaeology Symposium, San Ignacio, Belize.
McKillop, H. \& E.C. Sills. 2013. Sustainable archaeological tourism of the Maya Paynes Creek project using 3D technology. Anthropology News May/June: 12-13.

-2017. The Paynes Creek salt works, Belize: a model for ancient Maya salt production, in J. Matthews $\&$ T.H. Guderjan (ed.) The value of things: 6786. Tucson: University of Arizona Press.

McKillop, H., E.C. Sills \& J. Harrison. 2010. A Late Holocene record of sea-level rise: the K'ak' Naab' underwater Maya site sediment record, Belize. ACUA Underwater Archaeology Proceedings 2010: 200-207.

McKillop, H., E.C. Sills \& V. Cellucci. 2014. The ancient Maya canoe paddle and the canoe from Paynes Creek National Park, Belize. Research Reports in Belizean Archaeology 11: 297-306.

Pendergast, D.M. 1982. Excavations at Altun Ha, Belize, 1964-1970, volume 2. Toronto: Royal Ontario Museum.

Prager, C.M. \& G.E. Braswell. 2016. Maya politics and ritual: an important new hieroglyphic text on a carved jade from Belize. Ancient Mesoamerica 27: 267-78. https://doi.org/10.1017/S095653611600033X

Reina, R.E. \& J. Monaghan. 1981. The ways of the Maya: salt production in Sacapulas, Guatemala. Expedition 23: 13-33.

Rochette, E. 2009. Jade in full: Prehispanic domestic production of wealth goods in the middle Motagua Valley, Guatemala, in K. Hirth (ed.) Housework: craft production and domestic economy in ancient Mesoamerica (Archaeological Papers of the American Anthropological Association 19): 20524. Arlington (VA): Wiley-Blackwell. https://oi.org/10.1111/j.1551-8248.2009. 01021.x

Seitz, R., G.E. Harlow, V.B. Sisson \& K.A. TAUBE. 2001. Formative jades and expanded jade sources in Guatemala. Antiquity 87: 687-88. https://doi.org/10.1017/S0003598X00089171

Shafer, H.J. \& T.R. Hester. 1990. The Puleston axe: a Late Preclassic Maya hafted tool from northern Belize, in M. Pohl (ed.) Ancient Maya wetland agriculture: 279-94. Boulder (CO): Westview.

SheETs, P.D. 2000. Provisioning the Ceren household: the vertical economy, village economy, and household economy in the southeastern Maya periphery. Ancient Mesoamerica 11: 217-30. https://doi.org/10.1017/S0956536100112039 
SMITH, C.W. 2003. Archaeological conservation using polymers: practical applications for organic artifact stabilization. College Station: Texas A\&M University Press.

Taube, K.A., V.B. Sisson, R. Seitz \& G.E. Harlow. 2004. The sourcing of Mesoamerican jade: expanded geological reconnaissance in the Motagua region, Guatemala, in K.A. Taube (ed.) Pre-Columbian art at Dumbarton Oaks 2: 203-28. Washington, D.C.: Dumbarton Oaks.
Toscano, M.A. \& I.G. Macintyre. 2003.

Corrected Western Atlantic sea-level curve for the last 11,000 years based on calibrated ${ }^{14} \mathrm{C}$ dates from Acropora palmata framework and intertidal mangrove peat. Coral Reefs 22: 257-70. https://doi.org/10.1007/s00338-003-0315-4

Wright, A.C.W., R.H. Romney, R.H. Arbuckle \& V.E. VIAL. 1959. Land in British Honduras: report of the British Honduras land use survey team (Colonial Research Publication 24). London: Colonial Office.

Received: 10 April 2018; Revised: 21 August 2018; Accepted: 4 September 2018

(C) Antiquity Publications Ltd, 2019 